\title{
HUMAN EQUALITY PROJECTS AS PREREQUISITES FOR A POSTHUMAN EMBRACE
}

\author{
PROJETOS DE IGUALDADE HUMANA COMO PRÉ-REQUISITOS \\ PARA UM ABRAÇO PÓS-HUMANO
}

\section{PROYECTOS DE IGUALDAD HUMANA COMO REQUISITOS PREVIOS PARA UM ABRAZO POST-HUMANO}

Jamila Raana Siddiqui ${ }^{1}$

\begin{abstract}
The posthuman curriculum is emancipatory, but its emancipatory potential is presently limited. Given current inequalities among humans, movement beyond the human begs the question, "movement beyond which human?" Posthumanist and postcolonial literature at the crux of this conflict is briefly reviewed, and a resolution to the disagreements is proposed: Posthumanists wishing to advance their agenda should consider joining the human equality projects of humanists, such that, in due time, a fuller conception of human may be used as a foundation from which to "post." This will likely be both more effective and more just.
\end{abstract}

Keywords: Posthumanism. Postcolonialism. Human. Equality. Curriculum Studies.

\section{RESUMO}

O currículo pós-humano é emancipador, mas seu potencial emancipatório está atualmente limitado. Levando-se em consideração as atuais desigualdades entre os seres humanos, o movimento além do humano pergunta: "É um movimento além de qual humano?" A corrente pós-humanista e da literatura pós-colonial se encontra neste conflito revisado brevemente neste artigo, propondo-se uma solução aos desacordos entre os desejos dos póshumanistas em avançar sua agenda deveriam consideram unir-se aos projetos de igualdade dos humanistas, de tal maneira que, em seu devido tempo, uma concepção mais ampla do humano pode ser utilizada como base no 'post'. Isso provavelmente será tanto mais eficaz quanto mais justo.

Palavras-chave: Pós-humanismo. Pós-colonialismo. Humano. Igualdade. Estudos Curriculares.

\section{RESUMEN}

El desarrollo del curriculum post-humano es emancipador, pero su potencial emancipatorio es actualmente limitado. Teniendo en cuenta las actuales desigualdades entre los seres humanos, el movimiento más allá de lo humano plantea la pregunta, "¿El movimiento más allá de cualquier humano?" La corriente posthumanista y de la literatura postcolonial se encuentra en este conflicto a lo que yo reviso brevemente, y ademas se propone una solución a los desacuerdos entre: Los posthumanistas que deseen avanzar su agenda deberían considerar unirse a los proyectos de igualdad de los humanistas, de tal manera que, a su debido tempo, una concepción más completa del ser humano puede ser utilizada como base desde la cual del "post". Esto probablemente será tanto eficaz y más justa.

Palabras-clave: Post-humanismo. Pós-colonialismo. Humano. Igualdad. Estúdios Curriculares.

\footnotetext{
${ }^{1}$ Doutoranda do Departamento de Currículo e Instrução da Universidade de Wisconsin, Madison, Estados Unidos. E-mail: jamila.r.siddiqui@gmail.com.

Recebido em: 15/04/2016 - Aprovado em: 25/05/2016.
}

\begin{tabular}{l|l|l|l|l|l|l|} 
(C) ETD-Educ. temat. digit. & Campinas, SP & v.18 & n. 2 & p.458-464 & abr./jun.2016 & ISSN 1676-2592
\end{tabular}




\section{INTRODUCTION ${ }^{2}$}

Many "isms" exist as loci of the hierarchies of human life: racism, sexism, ableism, classism, ageism, etc. Each of these isms are entry points for socio-cultural critique to question and challenge inequalities and oppressive systems that have resulted from their hierarchical nature. Thus, each is worthy of consideration for further study.

Yet, there exists another, infrequently acknowledged ism that, because of its consistent intersection with all of the above mentioned isms, has the potential to obliterate them all: speciesism (Deckha, 2008). Human superiority over other species assumes the existence of the "human" when contrasted with the "non-human." This comparative and hierarchical organization of species models a comparative and hierarchical structure to be mimicked by the within-species isms mentioned above (Deckha). Furthermore, without the presumption of a uniquely "human" existence, notions of human inequality cease to exist.

Or do they? Can blurring the lines of what counts as human and troubling its play in humanism also blur and trouble the structural inequalities that haunt human identity? Or would that be ineffective - perhaps even disrespectful - amidst a continuing humanistic struggle by those who are Othered by their human, or effectually non-human, identities? Essentially, are we ready for the post-humanist curriculum that is advanced by this challenge to the human as a superior species?

Tension between posthumanists and equality advocates of the humanist kind have proliferated in the past couple of decades. After exploring this tension further below, I propose a resolution that allows for both parties involved to find solace in due time - a way to become ready for the posthumanist curriculum to be taken up in life and learning.

\section{POSTHUMANISM'S SOLUTION TO THE PERILS OF HUMAN IDENTITY AND INEQUALITY}

Posthumanism and related post movements (e.g. poststructuralism and postmodernism) simultaneously engage with and critique human identity and its correlated political issues. These post movements claim, generally speaking, that their solution - one which attacks the structure of hierarchical categorization that is the foundation upon which categories of otherness come to exist - is the most effective due to its total demolition of this foundation that would continue to replicate itself if given the chance (Snaza, 2015). Without categories, comparisons cannot be made and nothing can be sorted into a "less than" category and then operated on accordingly. Thus, the solution is to avoid any chance of eternally-stable and/or completely-total categories of identity. This is a counter-hegemonic,

\footnotetext{
2 This paper was presented on April 11, 2016 at the $100^{\text {th }}$ Annual Meeting of the American Educational Research Association in Washington, D.C., USA. It has been adapted for publication in this journal.
} 
emancipatory project for the marginalized; it just takes a form different from that of the more familiar emancipatory projects of humanism, which utilize stable and complete identity categories (Carlson, 2015).

The point of entry into foundational critique by posthuman theory is the human itself (Snaza \& Weaver, 2015). The human is a category of identity among species, arising from modernity's foundations. It also is a foundation itself, one for further divisions of the species into human identities (Deckha, 2008). Thus, it is a ripe entry point for political projects wishing to destabilize the comparative hierarchy of the moment: "If it is correct to read species as inextricably entwined with constructs of race, gender, and culture to the extent all such differences are born of one another and grow together in meaning, then riding within humanist confines will prove counterproductive for any emancipatory project. What is more, the analysis offered will be incomplete" because it under-acknowledges speciesism (Deckha, 2008, p. 260) and the political or partisan nature of stating one is human (Snaza, 2015). This is a call for an attack at the species level, rather than levels of race, gender, ability, class, etc.

Plans for attack vary given multiple iterations of posthumanisms at present (Snaza \& Weaver, 2015; Weaver, 2010). Even the domains that the theories reach range from emphasis on the human becoming-animal, to becoming-earth, to becoming-machine (Braidotti, 2013). So, while not yet (or perhaps never) a cohesive plan of attack against speciesism, the consistent departure from anthropocentrism by posthumanists as their flavor of political intervention among equality projects is worth taking note: "If our politics were not precisely limited to human beings and human concerns, then it would not have any meaning to treat someone 'as if' they are not human" (Snaza, 2015, p. 27). In other words, it is considered most important and effective to engage in becoming other than human as a political act, rather than embrace humanist human identities and attack their related isms.

We are in a posthuman era (Braidotti, 2013; Weaver, 2010). (Post)human identity is more complex than ever: "Our present moment is beset by problems - biotechnology, bioethics, biopolitics, computer programming and hacking, surveillance, factory farming and agri-business, GMOs, extinction, pollution, climate change - that evade and elude our present (humanist) forms of politics and community" (Snaza, 2015, p. 21). New kinds of control societies, exceeding those of humanism, are beginning to emerge (Hayles, 2004). Essentially, posthuman identity - if there is to be such a thing — is crafting a terrain of land whose patrol is in terms yet to be decided but with potential for just as much abuse and wrongdoing as what has arisen from human identity categories and hierarchies. A posthuman plan of attack addresses these undeniable human and posthuman issues.

\section{CRITICISM OF POSTHUMANISM'S SOLUTION FROM THE MARGINALIZED}

The posthuman solution to inequality finds poor reception among the audience it aims to help. Critiques of posthumanism from those involved in equality, emancipatory, and social 
justice movements are plenty. Zakiyyah Iman Jackson notes the crux of these critiques: "What and crucially whose conception of humanity are we moving beyond? Moreover, what is entailed in the very notion of a beyond?" (2015, p. 215). I highlight scholarly work that explores these questions below.

Several post-colonial scholars claim that the human is inextricably raced, thus to consider it complete, total, and universal is quite false. "Human" is not actually a valueneutral term, because "whiteness is the hidden designation of so-called value-neutral terms," according to Lewis Gordon (1998, p. 41). Gordon is taking note of the pervasiveness of a Eurocentric lens through which all, including the human, is presently conceptualized and normalized (Wynter, 2003). This Eurocentrism, as a limited lens through which to craft representation, is precisely what is sidestepped, to a fault, by posthumanists (Jackson, 2013). Jackson claims that "a call for movement in the direction of the 'beyond,' issued in a manner that suggests that this call is without location, and therefore with the appearance of incognizance regarding its situated claims and internal limits, returns us to a Eurocentric transcendentalism long challenged" (Jackson, 2015, p. 217).

Is it possible to move beyond the Eurocentric lens in this movement beyond the human? Perhaps, as Jackson alludes, the solution is not moving beyond the human to begin with. Instead of relying on what is a very limited understanding of human from which a launch toward the "beyond" is anchored, Jackson suggests remaining within humanity to transform it. Engaging non-Western epistemologies and philosophies that entertain appearances of the human outside of those imposed by Western imperialism will provide the human the freedom it needs to mutate into something new (Jackson, 2015). We may never know what constitutes a full or complete humanity, but this "new humanity" telos proposed by Jackson has the potential to address the bountiful challenges of 21 st century existence without implying an invisibility to race.

Why is it so important to retain an understanding of identity categories such as race? Lewis Gordon addresses this in relation to African Americans: "The problem is that without their blackness, they would disappear, without addressing their blackness, the ethical question of how black people should be treated - as all people should be treated, with respect, with dignity - would be evaded" (1998, p. 42). Identity categories, albeit the demise of many post philosophies, are a representative means through which political action can operate in working toward equality for all. Equality for all is closely linked to equality $\boldsymbol{o f}$ all, the latter found in the neutral use of "human" by posthumanism. I explain further in my resolution below.

Using human in a neutral sense is a privilege exercised by posthuman theory that does not get to be exercised by all. Some critics of posthumanism claim that only those who have not been marred by humanism's categorizing, sorting, and othering are privileged enough to embrace a posthuman perspective: "[D]ominant groups can 'give up' humanism for the simple fact that their humanity is presumed, while other communities have struggled too long for the humanistic prize" (Gordon, 1998, p. 39). The Others continue to be held in place 
as nonhumans or less than humans, thus they have no platform of humanity from which it feels comfortable to launch into a post-humanity. Only the privileged are in a place to dissolve their human bounds.

\section{MY PROPOSED RESOLUTION: WHEN YOU CAN'T (OR SHOULDN'T) BEAT THEM, JOIN THEM}

As a posthumanist who is also quite Othered, I have been stuck at this impasse of dual-direction critique for all of my academic years thus far. Only recently have I begun to form a potential, actionable solution to these competing solutions. My initial resolve is sketched in the assertions below.

Inequality remains in the human category, at present. Evidence of a continuing, pervasive disadvantage and hardship of those who are Othered is plentiful at the time of writing of this paper (July 2015): Growing media coverage of protests against the numerous instances of police killing black Americans; the repeated attack of religious institutions, such as the black church, by those who hold white supremacist beliefs; the Black Lives Matter movement gaining popularity and strength; and LGBT students struggling to find institutional protection from the harassment and assault they frequently face among peers in educational settings. These select examples begin, but do not fully capture, the entirety of the injustices that continue in the United States, as well as across the world, as a result of categorizing humans and placing them in a hierarchy of "legitimate" to "illegitimate," or "human" to "non-human." But there is no denying that these inequalities exist and are quite prominent for those who are punished for their location outside of a dominant domain.

Because the present state of the human category legitimizes only certain kinds of humanity, as evidenced by persistent inequalities, "human" is currently partial in its representation. To post (v.) the present human would be to move forward from only a particular kind of human, rather than all of humanity. It is likely, as the post-colonial scholars referenced in this paper noted, that Post-Eurocentric humanism is still Eurocentric. Thus, posting present humanism would perpetuate the structural inequality that Post work is looking to explode.

Only when the epistemologies and ontologies of humanism are expanded to include the fullest range possible will there be a humanism complete enough from which a posthumanism that does not simultaneously recapitulate the inequalities of present-day humanism can be launched. All of the various iterations of the human must be equalized in legitimacy as a prerequisite to actualizing posthumanism. At present, posthumanism is simply a potential.

Those who are interested in advancing posthumanism should consider joining with the movements of the marginalized to remediate inequalities in order to complete the prerequisite work needed for posthumanism to be successful in dismantling the category of human as it operates in humanism. Without the completion of this prerequisite work, I fear that post- 
humanistic movements will be not only ineffective, but also unjust. With a more equal epistemological and ontological human manifestation, in time, posthumanism's possibility for foundational change and movement toward the new seems infinite.

\section{CODA}

Knowledges and subjectivities have been in their plural form in curriculum studies for quite some time. This is a positive step toward a greater awareness of pure difference. Posthumanisms invite even more dimensions of difference into human awareness - of ecologies and object ontologies previously unrecognized or under-recognized.

This is exciting. Now we have new frames from which to think, new objects to think about, and new tools to use to break free from old chains. The sea of difference appears larger, and education of the human can grow and stretch to accommodate this new vastness that the human finds itself in. Curriculum studies gains an even larger playground.

Such outward-reaching onto-epistemological shifts seem to be trending in higher education, as I note in my forthcoming Ph.D. dissertation. Yet, amidst the excitement of these new frontiers, care should be taken not to lose sight of these as human epistemologies subject to human fallacies. Just as the human has demanded an unfair inequality across species, so has inequality risen within its own kind. This, I have not been allowed to forget.

\section{REFERENCES}

BRAIDOTTI, Rosi. The Posthuman. Cambridge, UK: Polity, 2013. 180 p.

CARLSON, Dennis. Foreward. In: SNAZA, Nathan; WEAVER, John (Ed.). Posthumanism and educational research. New York, NY: Routledge, 2015, p. 09-12.

DECKHA, Maneesha. Intersectionality and posthumanist visions of equality. Wisconsin Journal of Law, Gender \& Society, Madison, v. 23, n. 02, p. 249-267. 2008. Disponível em: 〈http://goo.gl/N35iKG〉. Acesso em: 15 abr. 2016. ISSN 1052-3421.

GORDON, Lewis R. African-American philosophy: theory, politics, and pedagogy. Philosophy of Education, p. 39-46. 1998. Disponível em: 〈http://goo.gl/aiy0z9〉. Acesso em: 15 abr. 2016.

HAYLES, N. Katherine. Refiguring the posthuman. Comparative Literature Studies, v. 41, n. 03, p. 311-316. 2004. Disponível em: 〈https://goo.gl/nZgCD0 >. Acesso em: 15 abr. 2016. ISSN 1528-4212.

JACKSON, Zakiyyah Iman. Animal: new directions in the theorization of race and posthumanism. Feminist Studies, v. 39, n. 03, p. 669-685. 2013. Disponível em: <https://goo.gl/X8Y1Vu>. Acesso em: 15 abr. 2016. ISSN 2153-3873. 
JACKSON, Zakiyyah Iman. Outer worlds: The persistence of race in movement "beyond the human". GLQ: A Journal of Lesbian and Gay Studies, v. 21, n. 02-03, p. 215-218. jun. 2015. Disponível em: <https://goo.gl/9F2USz>. Acesso em: 15 abr. 2016. ISSN 1527-9375.

SNAZA, Nathan. Toward a genealogy of educational humanism. In SNAZA, Nathan; WEAVER, John (Ed.). Posthumanism and educational research. New York, NY: Routledge, 2015. p. 17-29.

SNAZA, Nathan; WEAVER, John. Introduction: education and the posthumanist turn. In: SNAZA, Nathan; WEAVER, John (Ed.). Posthumanism and educational research. New York, NY: Routledge, 2015. p. 1-15.

WEAVER, John. Educating the posthuman: biosciences, fiction, and curriculum studies. Rotterdam: Sense Publishers, 2010. 153 p.

WYNTER, Sylvia. Unsettling the coloniality of being/power/truth/freedom: Towards the human, after man, its overrepresentation--An argument. CR: The New Centennial Review, v. 03, n. 03, p. 257-337. 2003. Disponível em: 〈https://goo.gl/b0y6BU>. Acesso em: 15 abr. 2016. ISSN 1532-687X.

\section{Como citar este documento:}

